\title{
The mechanical properties of AISi coatings made by PVD technology
}

\author{
Mechaniczne właściwości powłok AlSi wykonanych technologią PVD
}

\section{BARBARA KUCHARSKA ANNA WRÓBEL-KNYSAK *}

The mechanical properties (microhardness and scratch test) of AISi coatings made by PVD magnetron sputtering method from alloys with 7-20\%Si were compared. Higher concentration of Si increased deformation resistance of the coating, expressed by depth of scratch. Improved mechanical properties had coatings from alloys modified by TiBAl refiner.

KEYWORDS: protective coatings, PVD coatings, AISi alloys

Porównano mechaniczne właściwości (mikrotwardość i test rysy) powłok AISi wykonanych metodą PVD magnetronowego rozpylania stopów o zawartości 7-20\% Si. Większe stężenie Si zwiększało opór odkształcania powłok wyrażony głębokością rysy. Lepsze właściwości mechaniczne miały powłoki ze stopów modyfikowanych TiBAI.

SŁOWA KLUCZOWE: powłoki ochronne, powłoki PVD, stopy AlSi

In the production of exhaust systems in the automotive industry, ferritic sheets hot-dip covered with AISi coatings are often used presently [1]. Al-based protective coatings constitute the main protection against the influence of a corrosive medium at elevated temperature, including exhaust gas [2, 3, 4]. The tendency of Si to crystallizing from liquids in the form large and acute-angled crystals causes the risk of breaking the continuity of coatings to occur during the press forming of parts, as well as during their bonding. This urges the manufacturers to look for technological solutions for the application of coatings on finished products among the PVD techniques.

The application of coatings by the PVD (Physical Vapour Deposition) method involves the deposition of a material, previously brought in a gaseous state, on a substrate. PVD techniques are currently among the most commonly used methods of producing nanocrystalline coatings of unique structural features [5]. To produce homogeneous multicomponent coatings, several discs of different materials are sputtered simultaneously in large vacuum installations. In this study, a single disc of a multi-component material was used. According to literature information, $\mathrm{Al}$ and $\mathrm{Si}$ show a different tendency to sputtering. It is estimated that aluminium sputters approx. 2 times faster than silicon [6]. Having in mind the different susceptibility of Al i Si to sputtering, as well as the varying thermal expansion of the phases ( $\alpha_{\mathrm{Al}}$ and $\left.\mathrm{Si}\right)$ [7] already in the coating, the effect of phase refining (by modification with the TiBAl refiner) in the sputtered alloys on the mechanical properties of coating was additionally determined in the study.

\footnotetext{
* Dr hab. inż. Barbara Kucharska prof. PCz. (bratek@wip.pcz.pl)-Instytu Inżynierii Materiałowej, Wydział Inżynierii Produkcji i Technologii Materiałów Politechniki Częstochowskiej; dr inż. Anna Wróbel-Knysak (aknysak@ tu.kielce.pl) - Katedra Mechaniki, Wydział Mechatroniki i Budowy Maszyn Politechniki Świętokrzyskiej
}

\section{Material and research methodology}

AISi coatings fabricated on the 1.4512 steel substrate in the magnetron sputtering technology were investigated. Sputtering discs were made from AISi casting alloys with the sub-, peri- and hypereutectoid composition, respectively: AISi7, AISi11 and AISi20. One of the coating series was fabricated from AISi11 and AISi20 subjected to modification with the TiBAl refiner during casting with the aim of refining the phases $\left(\alpha_{\mathrm{Al}}\right.$ and $\left.\mathrm{Si}\right)$. The chemical composition of the coatings, as determined on their surface, and coating thicknesses are given in the table.

TABLE. Chemical composition (EDX) and thickness of the test coatings. $M$ - coating of an alloy modified with TiBAl

\begin{tabular}{|l|c|c|c|}
\hline \multicolumn{1}{|c|}{ Coating } & Al, \%mas. & Si, \%mas. & Thickness, $\mathrm{mm}$ \\
\hline AISi7 & 92,8 & 7,2 & 9,00 \\
\hline AISi11 & 87,3 & 12,7 & 9,67 \\
\hline AISi11-M & 87,6 & 12,4 & 9,45 \\
\hline AISi20 & 83,9 & 16,1 & 10,80 \\
\hline AISi20-M & 78,9 & 21,1 & 10,80 \\
\hline
\end{tabular}

The mechanical properties of the coatings were assessed in the hardness test by the Knopp method on a Future-Tech FV-7 tester under a load of 10G $(\sim 98,1 \mathrm{mN})$, making 3-5 impressions. In addition, the scratch test was performed on a Revetest Xpress CSM Instrument, whereby a $5 \mathrm{~mm}$-long scratch was made with a force ramping from $1 \mathrm{~N}$ to $15 \mathrm{~N}$.

The microstructures of the obtained coatings were similar in character: silicon crystallites (Si) occurred against a background of the aluminium matrix $\left(\alpha_{A I}\right)$. It was observed that on the coating cross-sections the silicon crystallites were arranged preferentially in the forms of chains along the direction perpendicular to the substrate (fig. 1).

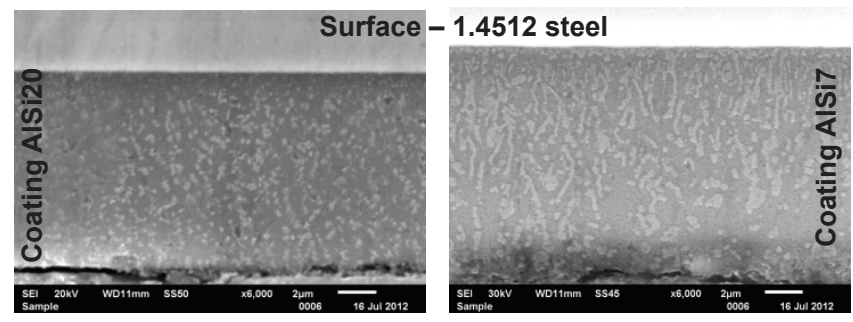

Fig. 1. AISi7 and AISi20 coating microstructures on the cross-section (a JEOL 6610LV scanning microscope), etched with 1\% HF

In the AISi7 and AISi12 coatings, the Si crystals were arranged uniformly over the entire coating thickness. In the AISi20, in the outer zone, the distribution of Si crystal was 
non-uniform. It can be supposed that for this reason the S concentration in this coating, as determined by micro-region analysis (EDX), also deviates from the Si concentration in the sputtered alloy.

\section{Investigation results and discussion}

The microhardness of the AISi7 and AISi11 alloy coatings was comparable, amounting to approx. $160 \mathrm{HV0.01.} \mathrm{The}$ hardness of the AISi20 alloy coating was much greater, reaching a value of $247 \mathrm{HV} 0.01$. Nevertheless, it should be noted that the determined hardness values of this coating showed a large scatter $(\sigma=8.5 \mu \mathrm{m})$, much greater than for the remaining coatings.

Sputtering the alloys modified with the TiBAl refiner resulted in a change in the hardness of the coatings made of those alloys. In the case of the AISi11 coating, a slight increase in hardness up to a value of 178 HV0.01 occurred. In the AISi20 coating, a similar hardness was obtained, though it was lower by almost $30 \%$ compared to that of the unmodified alloy coating (fig. 2).

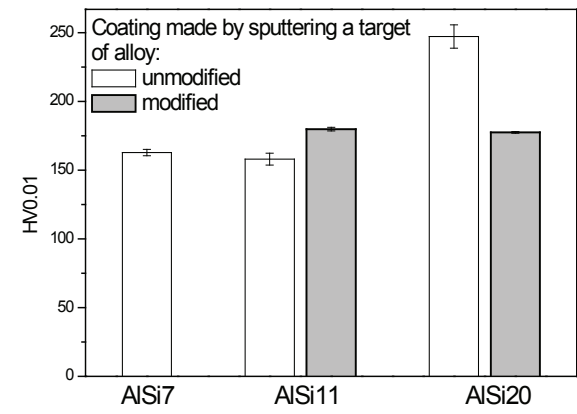

Fig. 2. The microhardness of AISi coatings

The scratch test results, in the form of a graphical presentation of variations in scratch depth under the load $P_{d}$ and during retracting indenter displacement $R_{d}$, are shown in figure $3 a$. All coatings retained cohesion and adhesion during the test, without any spalling and cracking (fig. $3 b$ ).

a)
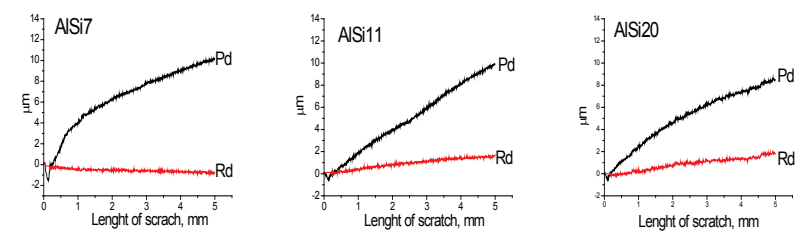

b)
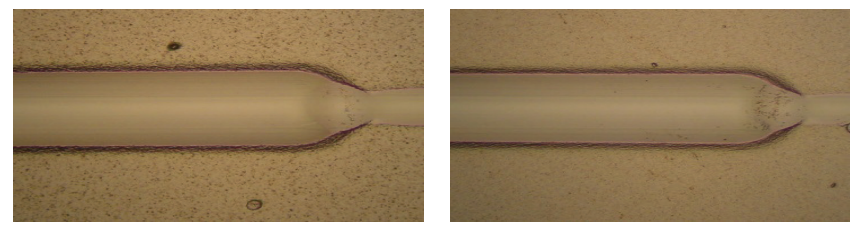

Fig. 3. Variations in scratch depth under loading (a); view of the scratches with the maximum depth, $\mathrm{Pd}(b)$

The greatest scratch depth ( $>10 \mu \mathrm{m}$ ), larger than the coating thickness, was obtained in the AISi7 alloy coating, while the smallest scratch depth $(<9 \mu \mathrm{m})$, and smaller than the coating depth, was obtained in the AISi20 alloy coating (fig. 4). The scratch depth was, therefore, in correlation with the Si concentration in the coatings.
In the scratch tests, no support for distinguishing the AISi20 coating was found, as was the case in the hardness tests. It should, therefore, be recognized that the higher hardness value of this coating, burdened also with a large error, reflects a non-uniform arrangement of silicon crystals in its outer zone. This implies that carrying out coating hardness tests as per the requirements of the method, i.e. with an impression depth of up to 0.1 of the coating thickness, may not be representative. Therefore, they were extended in the study by adding the measurement by the scratch method.

The measurements of the scratch depth, Pd, show an advantageous effect of the modification of the AISi alloys designed for sputtering. Scratches in coatings fabricated from such alloys had a depth smaller by 3 to $6 \%$, respectively, for the AISi11 and AISi20 coatings.

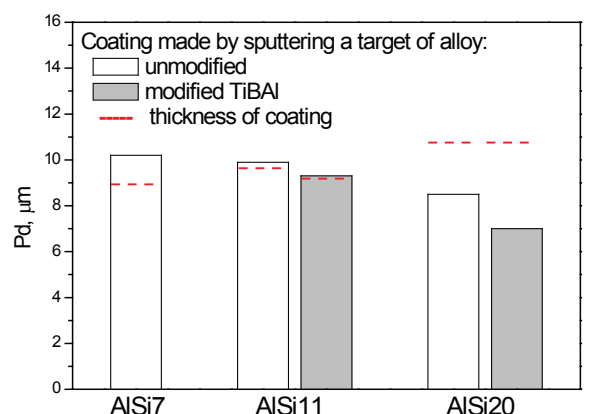

Fig. 4. The depth of scratches in coatings under a load of $15 \mathrm{~N}$

\section{Summary}

A relationship between the silicon concentration in AISi alloy PVD coatings and their susceptibility to deformations under loading has been found in the study. The highest susceptibility to deformations, as expressed by the scratch depth, under a load of $15 \mathrm{~N}$ is exhibited by AISi7 alloy coatings, while the lowest susceptibility, by AISi20 alloy coatings.

Coatings fabricated from AISi alloys modified by the Ti$\mathrm{BAl}$ refiner are characterized by a hardening as expressed by an increase in HV0.01 hardness by approx. 10\%, and a smaller scratch depth $\mathrm{Pd}$ by $3 \div 6 \%$, compared to coatings made from unmodified alloys. The higher mechanical properties of the coatings are due to more uniform sputtering of the alloy with a refined structure.

\section{LITERATURE}

1. Miller W.S., Zhuang L., Bottema J. „Recent development in aluminium alloys for the automotive industry”. Mater Sci Eng. A 280 (2000): s. 37-49.

2. Swadźba L., Moskal G., Hetmańczyk M., Mendala B., Jarczyk G. „Longterm cyclic oxidation of Al-Si diffusion coatings deposited by Arc-PVD on TiAICrNb alloy”. Surf Coat Tech. 184 (2004): s. 93-101.

3. Żaba K. ,The influence of annealing temperature and time on the structure and features of the Al-Si coatings on steel sheets, purposed for pressured welded pipes applied in exhaust systems". Arch Civ Mech Eng. 9, 2 (2009): s. 145-152.

4. Zandrahimi M., Vatandoost J., Ebrahimifar H. „Al, Si, and Al-Si coatings to improve the high-temperature oxidation resistance of AISI 304 stainless steel". Oxid Met. (2011): s. 347-358

5. Wendler B., Rylska D., Rylski A., Jachowicz M., Kaczmarek Ł., Pawlak W., Liśkiewicz T. „Powłoki ochronne na stopach metali osadzane metodami PVD”. Inż. Powierzchni. 2 (2005): s. 14-18.

6. Terwagne G., Bodart F. „Aluminium and silicon determination on two SiAl sputter targets used for magnetron sputtering". Nucl Instrum Meth. B 158 (1999): s. 683-688.

7. Kucharska B., Wróbel A., Kulej E., Nitkiewicz Z. "The X-ray measurement of the thermal expansibility of $\mathrm{Al}-\mathrm{Si}$ alloy in the form of cast and a protective coating on steel”. Solid State Phenom. 163 (2010): s. $286-290$. 